\title{
Sobre la apropiación de la escultura de San Ignacio de Loyola o el Lenin connotado
}

\section{About appropriation of San Ignacio de Loyola or the connotated Lenin}

\author{
Edgar Andrés Vallejo Erazo \\ Licenciado en Ciencias Sociales, Universidad de Nariño. \\ Auxiliar en Asuntos Culturales, Banco de la República \\ Estudiante de Maestría en Estudios Latinoamericanos, Centro de Estudios e Investigaciones \\ Latinoamericanas - CEILAT- \\ Email: evalleer@banrep.gov.co
}

Doi: https://doi.org/10.22267/rceilat.214849.103

"La realidad histórica tiene muchas maneras de ocultarse. Una de las eficaces consiste en mostrarse a la vista de todos"

Octavio Paz (2006)

\section{Resumen}

Sobre la crítica dirigida hacia una historia hegemónica del documento escrito, hacia los estudios tradicionales del arte y la poca relevancia de los estudios de recepción en historia en general, se realiza esta aproximación teórica, que busca no solo realzar la importancia académica de objetos artísticos no estudiados tradicionalmente, ya sea por el límite de referencias históricas existentes, o por la aparente frivolidad en el conocimiento del pasado que estos puedan arrojar, sino que pretende analizarlos sobre otro tipo de lente histórico, que permita comprender a profundidad estos objetos como insumos imprescindibles para el estudio de las formas de interpretación colectiva y su devenir en el tiempo.

A partir de la teoría de recepción (Keith Moxey, 2015 y Didi-Huberman, 2018) en diálogo con Roger Chartier (2019), se desarrolla dicha propuesta teórica. Ergo, se toma como objeto de análisis, el estudio de una leyenda de la ciudad de San Juan de Pasto, Colombia; la re significación de la escultura de San Ignacio de Loyola, hacia la efigie de Vladimir Lenin, y a través de un trabajo de critica historiográfica, que pone a dialogar los estudios tradicionales que se han hecho de la misma, con las teorías del giro icónico, y la teoría de la recepción, se procede a estudiar no solo la génesis de la obra, sino su re-significación, es decir, la historia de su apropiación.

Palabras clave: Apropiación cultural; Historia cultural; Historia del arte; San Ignacio de Loyola; Lenin; Pasto. 


\begin{abstract}
About a critic aiming towards an hegemonic history of the written document, towards traditional studies on art and the relevance of reception studies in general, this theoretical approximation is made, looking for enhance the academic relevance of artistic objects not traditionally studied, due to the limited historic references or the levity on the past knowledge these might bring, pretending to analyze them under a different type of historical perspective that allows to understand these objects deeply as indispensable income for the studies on different forms of collective interpretation and their becoming through time.
\end{abstract}

Throughout the Reception Theory (Keith Moxey, 2015 \& Didi-Huberman, 2018) in dialogue with Roger Chartier (2019) the afore mentioned theoretical proposal is developed. Therefore, the study of a legend form San Juan de Pasto (Colombia) is taken as subject of analysis; the resignification of San Ignacio de Loyola, towards Vladimir Lenin effigy. Additionally, it is analyzed through historiographic critic work, that matches traditional studies with iconic turn theories and the reception theory, taking into account not only the origin of the pieces is studied, but its resignification, meaning the history of its appropriation.

Keywords: Cultural appropriation; Cultural history; Art history; San Ignacio de Loyola; Lenin; Pasto

\section{Introducción}

Dentro del amplio campo de estudio que alberga la historia del arte, la historia cultural y la social, existen terrenos poco trabajados y profundizados a los cuales los investigadores generalmente no les prestan mucha atención. Estos terrenos entre otros, los constituyen los procesos de circulación, de apropiación y de recepción, en los que los objetos o manifestaciones culturales escapan del sentido e intención primaria por los cuales fueron fabricados, e ingresan en el terreno de la comunidad que los recepciona, hacia su cotidianidad, al dominio de la contextualidad, la cual les otorga nuevos significados, en muchos casos totalmente opuestos a los originales.

Aquellos terrenos se presentan como inaccesibles al ojo tradicional del historiador, ello principalmente por no contar con un importante acervo documental que permita su investigación, puesto que se escapan de los terrenos de las fuentes archivo-documentales, habituales en el taller de Clio; ¿Qué hacer entonces cuando la falta de documentos no permite llegar a conocer el origen y el significado primario de aquel objeto estudiado?, ¿Cómo proceder cuando aquellos objetos u obras han sido resignificadas por los receptores y aparentemente solo se conservan la interpretación recepcionada?, ¿sería posible hacer algún tipo de historia de la misma en esas condiciones? ¿o sería frívolo e improductivo pensar en estudios históricos solventados sobre los procesos de re-significación?

A criterio del presente autor, y retomando los planteamientos del "cole- 
Vallejo Erazo, E. A. (2021). Sobre la apropiación de la escultura de San Ignacio de Loyola o el Lenin connotado. Estudios Latinoamericanos, ISSN (Impr) 0123-0301- ISSN (en línea) 2665-329X, 48, 145-168.

gio invisible" de la nueva historia cultural $^{1}$, no es improductivo investigar sobre aquellos terrenos que exponen los procesos de circulación, apropiación y recepción, ya que este tipo de espacios evidencian capas profundas de entramados simbólicos, que trastocan todas las dimensiones del ser humano, en las cuales se gestan las dinámicas de percepción, conformación y construcción de una forma de realidad específica, que define los marcos y categorías por las cuales se interpreta lo real, y cómo ellos se modifican temporalmente producto de las tensiones que se han ido construyendo históricamente.

1 "El colegio invisible" alude, según Serna y Pons (2005), a las conexiones metodológicas y teóricas entre algunos historiadores de la cultura: Roger Chartier, Peter Burke, Carlo Ginzburg, Robert Darton y Natalie Davis, quienes comparten algunas afinidades en un modo particular de hacer historia. "En sociología de la ciencia, esta expresión [colegio invisible] designa aquel ámbito en el que unos objetos comunes de investigación, unos procedimientos y unos métodos compartidos acercan a investigadores que pueden estar geográficamente distantes" (Serna y Pons, 2005, p.22). Entre sus afinidades está "el abandono al convencionalismo de la profesión y de los hábitos adquiridos en la forma y en los objetos tratados [...] Suelen [también] centrarse en episodios y circunstancias que, al final, solo son una pequeña parte de su sociedad y de su tiempo [...] son a la vez vías de acceso tentativas que nos llevan a aquel mundo que hemos perdido, lo cual es ya, en sí mismo, una exploración de historia propiamente cultural. ¿Por qué razón? Porque el investigador se obliga a captar los esquemas culturales de los antepasados con el fin de entender las razones de sus actos y las intenciones que pregonaron y para ello han de reducir su escala de observación abordando a individuos o a comunidades manejables" (Serna y Pons, 2005, pp. 23-24).
Aquellos terrenos, por su característica misma de remitirse hacia las tramas simbólicas culturales, perforan los limites muchas veces rígidos de los tipos de historia antes nombrados, crean incisiones en las cuales el objeto de estudio se filtra, se desborda de sus fronteras reclamando la necesidad de un lente completamente diferente, que permita comprender las relaciones y tramas simbólicas a las cuales aluden. Por tanto, el presente trabajo, a través de un dialogo entre la teoría de la recepción de Keith Moxey (2015) y Didi-Huberman (2018) con la historia social de la cultura de Roger Chartier (1992), crea un espacio para la revalorización de los objetos/fuente infravalorados tradicionalmente, plantea un acercamiento investigativo a nuevas formas de estudio que no descuiden los procesos de apropiación. Ergo, se toma como ejemplo a la crítica establecida y a la propuesta teórica planteada, el estudio de una leyenda local de la ciudad de San Juan de Pasto; la transmutación y connotación simbólica de la escultura de San Ignacio De Loyola, hacia la efigie de Vladimir Lenin, y a través de un trabajo de critica historiográfica, que pone a dialogar los estudios tradicionales que se han hecho de la misma, con las teorías del giro icónico, y la teoría de la recepción, se procede a estudiar no solo la génesis de la obra, sino el porqué del nacimiento de su re-significación, es decir, la historia de su apropiación.

\section{Método}

Este trabajo articula polos académicos generalmente desunidos sobre la 
base de un espacio de reflexión teórica que oscila entre la historia del arte, representada por el giro icónico y la historia social de la cultura representada por Roger Chartier. Para el estudio de la escultura se procede teniendo en cuenta los postulados teóricos anteriores, sobre tres instancias disciplinarias interrelacionadas: una primera instancia histórica, trabajada gracias a la revisión de textos historiográficos regionales y del papel periódico "Ilustración nariñense" procedente del periodo temporal de 1932 a 1950. Segundo, una instancia estética e iconográfica, abordada tomando en cuenta los análisis iconográficos religiosos, y un ejercicio de comparación con vitrales procedentes de España y otras imágenes de estética ignaciana. Por último, una propia del "utillaje mental" , estudiada partiendo de una visión arqueológica y/o anacrónica (Didi-Huberman, 2018, p. 57-59) de la representación de la imagen, que inicia con el estrato de tiempo más próximo al presente inmediato, desde el cual el historiador se aproxima al pasado. A partir de él se analizarán las lecturas que se realizan sobre la efigie, la apropiación y construcción de significado y sentido propio de los lectores contemporáneos, y cómo dichas lecturas también se conectan a formas de percepción gestadas en un estrato temporal anterior, relacionándose con la experiencia heredada en la construcción de una identidad colectiva regional.

2 El utillaje mental, noción pilar del pensamiento de Febvre, es "el conjunto de las categorías de percepción, de conceptualización, de expresión y de acción que estructuran tanto la experiencia individual como colectiva" (Burguiere, 1991, p.472)
Lo anterior se apoyó tanto en una revisión documental del papel periódico "Ilustración nariñense", la revista "Cultura nariñense", los estados del arte sobre historia regional y la recopilación de fuentes orales con ayuda de entrevistas semiestructuradas y recopilación de comentarios y debates surgidos en las redes sociales.

\section{Una escultura, dos historias}

Cuando se menciona que existe un significado atribuido, o connotado a la escultura de San Ignacio de Loyola, ubicada en el frontis de la iglesia de Cristo Rey, en San Juan de Pasto (Figura 1), se ingresa en una instancia fenomenológica, estética e histórica debatible, debatida e infravalorada, dentro y fuera de la academia. La leyenda que genera ese tipo de circunstancias menciona que:

En Pasto, la "Ciudad Sorpresa" colombiana, hace unos 65 años, aunque un poco contrario. Cuando se terminaba de construir la Iglesia de Cristo Rey, de la comunidad jesuita, una de las más importantes de la ciudad y ubicada en pleno centro, uno de sus superiores encargó tallar una estatua de mármol que evocara a San Ignacio de Loyola fundador de la Compañía de Jesús. El trabajo se ordenó en Cuenca (Ecuador) a un reconocido escultor que al parecer no cumplió oportunamente con el encargo. Según lo refiere hoy el arquitecto historiador Mario Hoyos, hace unos 20 años conoció una versión contada con algo de sigilo por un religioso. El mármol de San Ignacio no estuvo a tiempo y tal vez por confusión o por la prisa, los jesuitas recibieron la efigie de un personaje parecido que ubicaron en el atrio de 
Vallejo Erazo, E. A. (2021). Sobre la apropiación de la escultura de San Ignacio de Loyola o el Lenin connotado. Estudios Latinoamericanos, ISSN (Impr) 0123-0301- ISSN (en línea) 2665-329X, 48, 145-168.

la iglesia. Expertos en el tema como el analista Álvaro Villota Viveros y el maestro en artes Álvaro Reyes (ex director cultural del Carnaval de Pasto), corroboran que esa talla corresponde en realidad a la figura de Vladimir Lenin, líder soviético propulsor de la revolución comunista (Artículo de opinión pública, tomado de Arévalo Rosero, 2013)

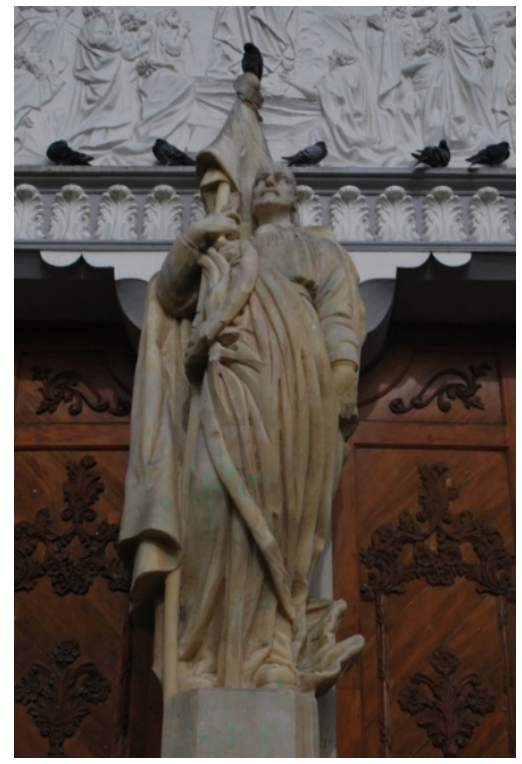

Figura 1. Escultura ubicada en el atrio de la Iglesia.

Fotografía tomada por el presente autor. 2019

Entre las diferentes versiones testimoniales recopiladas ${ }^{3}$, se encuentran

3 Dichos testimonios orales, se recopilaron a través de entrevistas semi-estructuradas que se realizaron a diferentes actores de la población, entre enero y agosto de 2020. La población entrevistada recoge tanto a académicos e investigadores regionales, como narradores orales, población universitaria y líderes de movimientos sociales de los 80 y 90 . Las entrevistas giraron sobre tres ejes; el del personaje real a quien alude y su procedencia, el significado que se le atribuye en el espacio en el cual se ubica y la algunos matices importantes frente a la procedencia y fin de la "imagen"4: algunas de ellas afirman que la efigie de Lenin fue encomendada por el gobierno cubano, en plena época de la revolución de los años 50, pero al no recibir el dinero correspondiente a la obra, el maestro dictaminó utilizarla para otro fin. Otra versión dictamina que la escultura en su proceso de traslado hasta Cuba, tránsito a Pasto y por razones desconocidas no pudo seguir hacia su destino final. Entonces fue adquirida por los jesuitas quienes, le encomendaron al mismo escultor que la modifique como la imagen de San Ignacio de Loyola ${ }^{5}$. En la mis-

importancia de dicha imagen y su significado para la ciudad o región.

4 No es fortuito el uso de la noción de imagen en este trabajo. Como afirma Alcala (2014) existe una gran diferencia entre el estudio de los objetos como obras de artes y como imágenes. Las primeras enfocadas en procesos estéticos y de producción y la segunda se dirige a su valor simbólico y representativo: "Cuando hablamos de imágenes, parece que nos referimos sobre todo al tema representado - una imagen representa o simboliza algo- y también como colorario a cuestiones sobre su función, su recepción $\mathrm{y}$, como ocurre con mucha frecuencia en el caso latinoamericano, su identidad" (p.15) Es en dicha línea, en un "más allá del arte" que se ubica este trabajo.

5 "Todo empieza en la época de la revolución cubana allá por la lejana década del 50. Debido al naciente comunismo de la isla, Castro encomendó a un artista ecuatoriano (los colombianos dicen que fue un artista quiteño) tallar una escultura de Vladimir Lenin. Por azares del destino esta estatua que jamás pisó tierra cubana llegó a Pasto y es ahí donde nace la leyenda. Dicha efigie al no ser adquirida por los cubanos es encargada por los Jesuítas quienes solicitan al mismo artista que la transforme en la imagen de San Ignacio, que hoy precede la entrada a la Iglesia. Para argumentar esto, la gente en Pasto 
ma línea, otras cuentan, que el escultor era un militante de izquierda, quien aprovechando una estatua que ya poseía, entregó a los jesuitas dicha efigie, sin ningún reclamo de su parte, con un fin económico y simbólico (Vivas, 29 de Enero 2020). Otras dictaminan que la imagen fue encargada por el grupo guerrillero colombiano M-19 y terminó como acto de protesta simbólica en el frontis de la iglesia ${ }^{6}$. Por último, existen las versiones que mezclan los componentes anteriormente descritos.

Todas estas versiones, llaman la atención por un fenómeno particular: la necesidad de atribuirle un origen específico de creación a la obra, que casualice la atribución de un significado totalmente diferente al planteado por la voz oficial y que re-defina la importancia de la estatua en el espacio simbólico de la ciudad. Contra este deseo de fundamentar cronológicamente la connotación del significado, se manifiesta la voz oficial que desmiente $\mathrm{y}$ desmitifica aquella leyenda urbana; la imagen claramente representa a San Ignacio de Loyola y cualquier otra atribución es simplemente producto de la subjetividad.

Al no existir aparentemente documentación que pueda corroborar el

se basa en que la imagen viste botas militares y que la túnica no es túnica sino la bandera de la revolución cubana." "Pequeños relatos de la historia.", relato publicado por Dylan Crux (2014) en el grupo de Facebook "Cuenca de Antaño".

6 Entrevista realizada al narrador oral local Miguel Eduardo Álvarez, el día 23 de marzo del 2020 . origen y mensaje comunicativo primario de la obra, sumado a una aparente trivialidad en este objeto de estudio, el centro de interés académico e histórico referido a la imagen pierde fuerza y se desplaza hacia objetos de investigación más "trascendentales". La respuesta académica, dictaminaría que aquello es simplemente una connotación (no histórica) producto de una visión pareidolica de la escultura, donde el ser humano ve simplemente lo que quiere ver. Ya que es inoperable cronológicamente que la estatua represente una efigie de Lenin.

Sin embargo, toda posible connotación de una obra responde a un proceso de trasferencia de su significado al receptor, y, de contra-trasferencia del receptor hacia la obra. Aquellos matices de la escultura, no son valoraciones fruto exclusivo de la subjetividad del ser humano, se desarrollan dentro de unas dinámicas en las cuales se ve inmerso el espacio de experiencia y el horizonte de expectativa específicos (Koselleck, 1993), bañados por una memoria cultural, que trastoca o redefine lo impuesto y que generan, junto a un espectro de libertad interpretativa que dan las nuevas experiencias que adquiere el lector, $y$ unos acontecimientos sincrónicos que lo trastocan, una determinada lectura de la efigie ${ }^{7}$.

7 El espacio de experiencia koselleckiano, entendido no solo como los acontecimientos incorporados y transmitidos por la memoria hasta el presente, sino también como las cargas y formas interpretativas que acompañan dichos acontecimientos, y que a su vez han generado matrices de interpretación. Siendo el marco interpretativo heredado que posee un individuo-comuni- 
Vallejo Erazo, E. A. (2021). Sobre la apropiación de la escultura de San Ignacio de Loyola o el Lenin connotado. Estudios Latinoamericanos, ISSN (Impr) 0123-0301- ISSN (en línea) 2665-329X, 48, 145-168.

Como se puede inferir, estas formas de leer la obra e interpretarla no son inmutables, ni únicas, son históricas, es decir, que cambian en el tiempo, por tanto, las atribuciones de significado también lo son y responden no únicamente a su delimitación cronológica primaria, (es decir, al significado definido en el espacio de creación de la obra, al cual es el único que generalmente se accede en los estudios históricos, estéticos e iconográficos de herencia winckelmanniana (Didi-Huberman, 2009, pp.9-44)) sino a múltiples formas de entenderla diacrónica y sincrónicamente. En consecuencia, el estudio de esa re-significación, es y debe ser un proyecto investigativo capital no solo para la comprensión de los modos particulares de interpretación colectiva hacia las últimas décadas del siglo pasado, en una ciudad marcada por procesos propios de la periferia, por circunstancias de relación multicultural y dinámicas de frontera, sino también como posibilidad para la desarticulacion de una historia del arte estática y positivista.

Las obras de arte como afirmaría Didi-Huberman, en palabras de Keith Moxey (2015), tienen una presencia fenomenológica, que las hace capaces de desafiar el tiempo, "su capacidad para eludir el marco histórico hace necesario reevaluarlas y reinterpretarlas a través del curso de su existencia" (p. 60). Una obra, no es atemporal, su significado no es inmutable, ni responde exclusivamente a su "origen generativo",

dad para leer y comprender su realidad.

8 La noción de "origen generativo", en este caso en diferentes temporalidades, se redefine, reconfigura, es discontinua, se relaciona con los espectadores en su contexto espacio-temporal gracias a las categorías de percepción, pero a la vez genera su propio proceso de recepción, que reconfigura las realidades sociales, históricas, culturales y estéticas. La obra de arte es una presencia viva que afecta el presente del individuo, y niega la inmovilidad del significado, puesto que perturba espacialmente al nuevo espectador que dialoga con ella.

A razón de esto, el significado de la obra no es solo comunicativo, es decir, que transporta una información netamente en el espacio y que culmina con la llegada de dicha información a un receptor-espectador. Emerge de un proceso igualmente importante de "transmisión", que lo reconfigura temporalmente, lo vuelve vivo, múltiple, connotado. Cuando la obra entra en relación con receptores en diferentes contextos temporales y espaciales, su significado connota, ya que dicho receptor no posee los mismos códigos y categorías de inter-

exclusivo, debe entenderse desde el pensamiento Herman Cohen (1902, p.32-36) y su definición lógica de origen, como aquella pretensión del historiador por encontrar la génesis de la obra, el significado primario y verdadero, inmutable que en este caso se dio a una obra de arte. Esta noción será opuesta a la retomada por Didi-Huberman (2018), quien defiende el argumento del origen no como génesis, sino como dialéctica entre supervivencia y ruptura, y a la cual se remitirá críticamente el presente autor.

9 Se remite a la noción de "transmitir" de Debray (2007): Si "comunicar [...] es el acto de transportar una información en el espacio, y transmitir [es el acto de] transportar una información en el tiempo" (p.2) 
pretación y decodificación que el emisor y el receptor original, posee nuevos códigos, nuevas circunstancias culturales, nuevas formas de percepción de la realidad, que son históricas, propias de su temporalidad, y que marcan por la misma característica de su espacio de experiencia una nueva relación signica y simbólica con la obra.

Aquella efigie ha construido su significado a través de tensiones históricas que aparecen en un tiempo específico, de circunstancias socio-históricas que han trastocado la realidad de las personas de la ciudad y que han conllevado a representar su influjo en la forma de percibir e interpretar los objetos que les son propios. Dichas tensiones generarían en cierta medida lo que Ferro Medina (2004), en su estudio sobre el culto a la Virgen de Las Lajas llamó "una batalla de signos"; una guerra por el significado principal de la imagen; una dialéctica entre lo sagrado y lo profano. En otras palabras, un proceso de resistencia que surge de lo popular hacia lo establecido y que no debe menospreciarse, ya que son estas, parafraseando el título del libro de James C. Scott (1985), una de las tantas "armas de los débiles"; un tipo de forma de respuesta hacia un poder cohercionante y que ha tenido vigencia por más de 5 siglos.

Ahora bien, para poder estudiar históricamente aquellos marcos de interpretación, aquellas categorías que delimitan la forma de pensar y leer la realidad y que generan fenomenológicamente la re-significación, es necesario derribar la hegemonía im- puesta en principio a la investigación archivo-documental y los pilares teóricos que aun definen a los estudios históricos del arte y la cultura, es decir, los tres ídolos de la tribu de los historiadores que Francois Simiand (1960) criticaba; el ídolo de los acontecimientos, el ídolo de los estudios políticos y principalmente, el ídolo de la cronología, y un cuarto y quinto ídolo que agregaría el autor de este trabajo, el ídolo de los estudios que se remiten exclusivamente al momento de creación de la obra ${ }^{10}$ y el ídolo de las fuentes archivo-documentales. A continuación, se profundizará en ello.

En la anterior leyenda se plasman dos visiones frente a la imagen de aquel singular San Ignacio de Loyola/Lenin, de ellas, sobresale por su poder y capital simbólico la voz oficial compuesta por la historia tradicional y el clero. Esta visión dictamina que el significado de la obra se atribuye exclusivamente al hecho de su concepción: al ser encomendada como una imagen de San Ignacio de Loyola, el significado de la misma debe corresponder lógicamente al patrono de los jesuitas. Aquello atañe no solo a un paradigma en historia del arte que hace primar los estudios formales, estéticos y ahistóricos de las obras, dimensionados exclusivamente en su

10 Se comparte la postura crítica realizada a la historia del arte clásica de herencia winckelmanniana, la cual estudia el pasado, como un acontecer muerto imposible de reanimar, el cual genera simplemente tristeza y nostalgia (Didi-Huberman, 2009, pp. 9-44), ergo, no afecta ni tiene vida fuera de su contexto de producción. 
Vallejo Erazo, E. A. (2021). Sobre la apropiación de la escultura de San Ignacio de Loyola o el Lenin connotado. Estudios Latinoamericanos, ISSN (Impr) 0123-0301- ISSN (en línea) 2665-329X, 48, 145-168.

contexto de producción, sino también a un modelo de interpretación netamente comunicativo y "unívoco" (Beuchot, 2016): El significado de la obra es dado exclusivamente en el primer acto de comunicación, donde el objeto al que se refiere la escultura responde netamente al que la comunidad que lo desea poseer le da, a priori de su producción. La obra, por tanto, adquiere su contenido simbólico no en relación a los espectadores, sino en relación al emisor original quien la dictamina. Su significado ya no cambiará, se estatiza en este primer acto comunicativo, aunque la obra genere procesos de transmisión ${ }^{11}$.

Todo ello se solventa además en una visión teleológica del tiempo histórico, que conlleva a temporalizar exclusivamente el proceso de creación y significación per-se, de manera cronológica, lo que Didi-Huberman (2018, p. 43) referiría al dominio de la eucronía; es decir, a aquella concepción de tiempo que enmarca el espectro de análisis del objeto investigado únicamente a su espacio de producción, en otras palabras a aquel ángulo convencional de estudio del "artista y su tiempo”. Desde dicha visión, se llega a concluir entonces que la escultura es de San Ignacio de Loyola, porque es la consumación lógica a la serie de acontecimientos que anteceden, causalizan y definen su significado:

11 Lo anterior podría ser entendido también desde el pensamiento de Gombrich (2010, p. 245) como una forma de suspensión de la incredulidad; un tipo de ceguera, que tiene por característica la ilusión de que existe solo un modo de interpretar el esquema visual al cual se enfrenta el observador.
Según José Vicente Agreda (2002) la construcción del templo de Cristo Rey inició con la demolición del templo de Santo Domingo, en julio de 1930. El 8 de mayo de 1931 se colocó la primera piedra con la presencia del padre Rafael Torres, prefecto apostólico del Magdalena. Los planos fueron elaborados por el jesuita Gorgoza, con el objetivo de materializar un templo en honor a su misma orden. Menciona Moreno (1979, p, 82) que el 21 de octubre de 1942, el templo es bendecido e inaugurado a través de celebraciones eucarísticas, a las cuales como se puede corroborar en la edición más próxima de "Ilustración Nariñense" (1942, p. 31), acuden personalidades importantes de la sociedad clerical y laica de Pasto y los alrededores. En 1945, estando en proceso de terminar las dos torres, una entrevista realizada al rector del colegio Javeriano, el padre Germán Fernández, revela la futura ubicación de la estatua de San Ignacio de Loyola:

El Frontis que a nuestro juicio y al de muchas personas entendidas no guardaba armonía ni proporción a la belleza arquitectónica del interior será mejor ornamentado. Mayor esbeltez se dará a las puertas con ornamentaciones adicionales que lleguen a la superficie desnuda de la pared. Al pie de la columna central que mira al exterior de la puerta principal será colocada una bellísima estatua de San Ignacio de Loyola en actitud de invitar a los fieles que entran a la casa de Dios, al silencio y a la oración. (Ilustración Nariñense, 1945, p.42).

Más tarde en 1948, en Cuenca, de 
la mano del maestro Eloy A. Campos Garcés (Figura. 2), se termina la escultura que se ubicaría en el frontis y puerta principal de la iglesia.

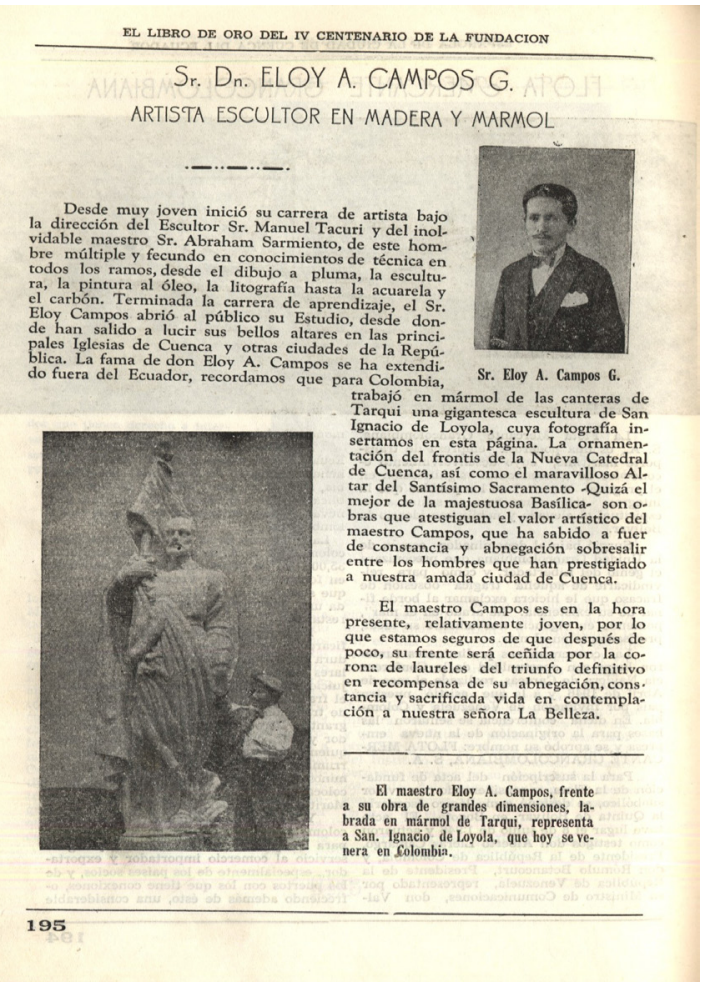

Figura 2. Artículo en "El Libro de oro. Edición conmemorativa del IV centenario de la fundación española de Cuenca del Ecuador”, de Ediciones El Tiempo (1957, $\mathrm{p}, 195)$

La conclusión racional de esta línea temporal culminaría en afirmar que el significado histórico de la obra es el que el padre Fernández manifestaría con anticipación: la escultura pertenece a San Ignacio, por encargo de la orden jesuita, ejecución oportuna por parte del maestro y ubicación espacial (en el parteluz ${ }^{12}$ ) en una igle-

12 Generalmente, las imágenes colocadas en el atrio de la iglesia o en su fachada, tienen el objetivo de recordar la advocación a la cual está subscrito el templo, se situaban en este sitio sia propia de la compañía de Jesús; lo que cumpliría un objetivo básico y habitual en la fundación de un nuevo templo, es decir, proveerlo de imaginería católica (Pérez Pérez, 2016, pp.81). El significado preestablecido guardaría una coherencia lógica, en la cronología anteriormente mencionada y en la dimensión simbólica de la orden mendicante. Con lo anterior, toda la delimitación del significado quedaría reducida a lo previamente estipulado, y con ello la investigación histórico-artística frente al objeto visual concluye, de manera que su interés en el espectro investigativo se desvanece sin más, dado que no habría más capas de información que se puedan encontrar.

La anterior visión cronológica del significado, corresponde y se manifiesta también en una perspectiva interpretativa de la iglesia y todos sus bienes muebles como unidad estética en sí misma, es decir que la línea cronológica no divide cada aspecto material del templo, sino que se desarrolla tomándolos como un todo estético. Desde esta postura, la iglesia no es un cumulo de sentidos estéticos separados, es una unidad con un mismo punto de creación y, por ende, con un mismo objetivo estético-religioso. Lo anterior delimita y determina el significado de sus partes inmuebles, no solo cronológicamente -en una temporalidad lineal de trasformación del templo de Santo Domingo hacia la Iglesia de Cristo Rey-, sino que ahoga

como una estrategia que buscaba hacer cotidiana su presencia entre los fieles (Pérez Pérez, 2016,p.139) 
Vallejo Erazo, E. A. (2021). Sobre la apropiación de la escultura de San Ignacio de Loyola o el Lenin connotado. Estudios Latinoamericanos, ISSN (Impr) 0123-0301- ISSN (en línea) 2665-329X, 48, 145-168.

la individualidad de los significados de cada bien artístico, por la preponderancia del sentido que se le da historiográficamente a la totalidad. Solo en algunos casos, cuando los objetos muebles ubicados dentro de ella escapan a ese espectro de delimitación temporal de su creación (entre 1931 a 1942), y se encuentran en periodos alejados a ese todo estético preconcebido, el significado de los mismos resalta por su individualidad: "La única imagen antigua y con bastante historia que actualmente podemos admirar en el templo es el Cristo de Sibundoy [que data del siglo XVII]" (Agreda, 2002, p. 296). Sin embargo, esta individualidad fácilmente se anexiona a la totalidad estética del templo. Lo mismo ocurre con las imágenes provenientes de Europa que se alojan aun hoy en la iglesia (Álvarez, 1985, pp. 113-114).

Que se desconozca otra información de la escultura, acontece de igual forma, por ese poder estético de la totalidad de la iglesia, y la línea cronológica que remarca el conjunto atenuando las particularidades ${ }^{13}$, sin

13 En una serie de artículos históricos se puede observar materializada esta doble perspectiva cronológica: Al referirse al templo de Cristo Rey, el Padre Eduardo Ospina, citado por José Vicente Agreda (2002) se enfoca en describir su unidad estética: "es gótico de transición. El frontis en su concepción original de tipo romano-gótico, a instancia del P. German Fernández, rector del colegio, fue sacado de ser un sencillo muro muy frio, sin gracia alguna y recibió la suntuosidad, belleza y viveza que actualmente ostenta, gracias a las indicaciones del P. Andres Bosset, eudista, arquitecto francés. Se le coloco en la parte superior del frontis la estatua de Cristo Rey, obra del escultor nariñense Marceliano Vallejo. embargo ese desconocimiento arroja una información historiográfica e histórica importante: sobre la primera, se evidencia que al ser una leyenda de connotaciones populares, escapa al espectro clásico que los estudios históricos regionales han definido (y que se relaciona directamente con una hegemonía del positivismo y el paradigma de la eucronia), en otras palabras que es y no hace parte de una investigación histórica rigurosa, importante y necesaria. Sobre la segunda, la falta de relevancia que tenía la obra, en relación a otras producciones artísticas dentro de la iglesia, vislumbrada en la casi nula referencialidad de esta imagen en la época, conducen a pensar que ella no adquiere importancia simbólica, sino exclusivamente cuando surge la leyenda sobre Lenin. Antes, pasa desapercibida, menospreciada por el poder estético de la unicidad del templo. Por tanto, se infiere que la imagen empieza a cobrar sentido y relevancia para el espectador, con y

Esta estatua está a 36 metros de altura. Se le dio más amplitud a la puerta principal y sus anchas puertas quedaron separadas por una columna de mármol a cuyo costado se yergue imponente [es aquí y solo aquí cuando se nombra la escultura] una estatua de S. Ignacio, en alabastro, fabricada en Cuenca, Ecuador" (p.296). En otro texto, Bastidas Urresty (2000) menciona en pocas líneas que "Las torres y fachada, se llenan de ornamentaciones y para elaborar la pintura y tallado de la imaginería se acude a prestigiosos artistas quiteños" (p.257), en relación al frontis solo agrega que "se destaca un gran rosetón y la estatua de Cristo Rey" (p.275). Otros, como Álvarez (1985) dan descripciones muy sucintas, de un análisis general de todo el templo: "La estatua en mármol de San Ignacio, en el atrio del templo, es una escultura ecuatoriana" (Álvarez, 1985, p.114). 
después de su re-significación, pues esta, le ha dado vida, reanimando y re-haciendo su "origen"14.

Cabría suponer que ello es consecuencia no solo de ese pensar monocrónico de la iglesia, que conlleva a una infravaloración del estudio de las connotaciones, sino un rezago del historicismo que criticaba Simiand (1960), o Benjamin (2013) con su "historia a contrapelo". Pero aquello es más complejo, puesto que, remite a los dominios de lo epistemológico, en los cuales, tanto la historia como disciplina en general, y sus especialidades de historia cultural y del arte (esta última de herencia Winckelmanniana), se estructuran desde la preponderancia no solo de un paradigma positivista aun imperante, sino también de una

14 En oposición a esa búsqueda de un origen de génesis, anteriormente descrito, Didi-Huberman (2018, pp.127-129) afirma, retomando a Walter Benjamin, que la noción de "origen" (Ursprung) es imperativo separarla de la noción de génesis de las cosas; ya que el origen es en realidad como un torbellino dinámico que está presente en cada objeto histórico, el cual puede aparecer en el transcurso de su cauce, es la posibilidad de apertura a lo que puede llegar a ser, la posibilidad de nuevas incursiones temporales, narrativas, teóricas, estilísticas, interpretativas que pueden estar o estarán latentes en la materialidad de la obra, en otras palabras, es una novedad y no el estrato eucrónico generalmente buscado; "en este sentido cristaliza dialécticamente la novedad y la repetición, la supervivencia y la ruptura" (Didi-Huberman, 2018, p.128). El origen por tanto no se halla en lo pasado, puesto que no existe, se construye. Como refiere Martínez Cleves (2018), al existir ausencias múltiples en lo pasado, al comprender que este se construye solo desde el presente, es entonces el presente el que otorga y crea ese pasado, partiendo de una observación determinada. visión eucrónica del tiempo histórico, que hace imposible pensar en un proceso de recepción de la obra, que desfase la línea temporal ya perfilada.

Con el reconocimiento de la heterocronicidad y la recepción de las obras, aquel dominio del positivismo y lo eucrónico (que había conllevado a que la investigación histórico-artística, se preocupe principalmente por comprender "el auténtico" significado de la obra, situada en su horizonte histórico primario y sus características estéticas inmutables), pueden desarticularse, puesto que se reconoce que la re-significación no surge en la misma línea temporal diacrónica de su creación, sino que se desarrolla en otra delimitación temporal, en otro estrato de tiempo presente en el mismo objeto, o en una latencia de significado, es decir, en una "anacronia" ${ }^{15}$, que

15 El concepto de anacronía debe entenderse en este trabajo tomando como referente los postulados teóricos desarrollados por Didi-Huberman (2018) y Keith Moxey (2015). Este último afirma de la anacrónica que: "Las obras de arte o, en verdad, muchas imágenes, tienen la capacidad de crear su propio tiempo para los espectadores atentos $[\ldots]$ Los objetos visuales perturban y alteran la cronología en vez de organizarla. Es este sentido anárquico de la temporalidad el que caracterizo como anacrónico. El tiempo anacrónico no puede reconciliarse con la arquitectura historicista que estructura con firmeza la historia del arte. Con demasiada frecuencia, la discusión sobre las obras de arte se ha limitado a revelar su importancia dentro de un horizonte histórico particular en lugar de reconocer su papel en periodos subsiguientes, incluyendo el presente... El mío está lejos de ser un argumento histórico. En lugar de abolir el sentido del tiempo, requiere que la relación temporal entre el pasado y el presente se piense de nuevo, a fin de poder escapar del efecto entumecedor de la 
Vallejo Erazo, E. A. (2021). Sobre la apropiación de la escultura de San Ignacio de Loyola o el Lenin connotado. Estudios Latinoamericanos, ISSN (Impr) 0123-0301- ISSN (en línea) 2665-329X, 48, 145-168.

le da una existencia ontológica, fuera de lo diacrónicamente establecido. El significado y sentido se desprenden de esa línea temporal que los determinaba y libre de lo in illo tempore religioso y/o lo prefigurado, re-construyen su significado, su origen y su devenir, con las nuevas temporalidades que los espectadores le otorgan. Este tipo de lente teórico, revela a la postre aquellos orígenes diversos, matizados y latentes que se ocultaban tras el dominio de lo eucrónico.

El historiador entonces ya no se puede situar "ante la imagen" como si esta estuviera delimitada exclusivamente por sus coordenadas de producción (autor, fecha, iconografía, formas). Por el contrario, una imagen, como lo enunciaba Warburg (Citado por Didi-Huberman, 2009, p. 35), es en realidad el resultado de movimientos que han sedimentado o cristalizado un valor adicional en ella, o en otras palabras unas "supervivencias" (Nachleben ${ }^{16)}$ de

tabla periódica" (Moxey, 2015, p.252). La anacronía es entonces la posibilidad de superación de la estatizada eucronía, va más allá de aquel ídolo de los estudios de creación y génesis, ya que reconoce la latencia y el síntoma (imagen-síntoma) de tiempos, tempos y experiencias diversas, que se yuxtaponen y sedimentan entre sí. En ese orden de ideas, la anacronía no es concebida como aquel "error capital" en el que puede caer el historiador, sino como fuente de conocimiento, que permite hacer inteligible la heterocronicidad y la poliritmia histórica inmersa en un mismo objeto de estudio.

16 Ahora bien, para este trabajo se rescata una cualidad esencial del Nachleben; la paradoja temporal de lo ahistórico y lo histórico a la cual se inscribe; las supervivencias tienen la característica de oscilar entre una transmisión ahistorica que las hace inmodificables y una presencia histórica sincrónica y diacrónica que posibilita lo pasado en la imagen.

Estos desbordes y sedimentaciones que subyacen en la obra, no pueden pensarse exclusivamente desde la materialidad (como supervivencias de formas pasadas en la imagen), sino que deben acoplarse también a una instancia antropológica, como el mismo Warburg lo planteaba (Didi,Huberman, 2009, p.36-44). Las nuevas atribuciones de significado y sentido que llegan al presente, pueden y deben concebirse también como supervivencias de un aspecto de lo pasado que ha quedado sedimentado sobre la imagen, las cuales no están sostenidas sobre un soporte material, sino sobre uno inmaterial, es decir, modificaciones simbólicas de su significado y sentido.

Ahora bien, para estudiar estas supervivencias es necesario acoplar el anterior corpus teórico a un modelo no de historia netamente del arte que se preocupe por sus relaciones formales intrínsecas, sino que se requiere de un modelo de historia más allegada a la "Kulturwissenschaft" que

re-contextualizarlas, es decir, que si bien estas se sedimentan en apropiaciones futuras, también llegan al presente sin ninguna modificación o cambio ante todo formal, en cierto sentido, una "sedimentación de lo diacrónico en la historia" (Vallejo Erazo, 2018), lo que permitiría comprenderlas como persistencias no cronológicas de un pasado que se creía desaparecido y modificado. Las supervivencias también traen consigo una carga histórica que hace remitir a su contexto de origen y desarrollo. Por tanto, el Nachleben, podría pensarse como una posible ventana no modificada, ni transfigurada hacia algunos aspectos del pasado, que han subsistido latentes en las obras. A la vez que es una posibilidad constante de sedimentación. 
Warburg, pero que además permita acoplar también el importante papel del receptor en estos procesos de sedimentación de significado en las obras. Por tanto, se ve pertinente llamar al debate al historiador Roger Chartier (1992), desde el cual, es posible no solo generar espacios de encuentro (normalmente no creados) entre historia cultural e historia del arte, sino complementar los estudios de "recepción histórica" ${ }^{17}$ hacia los cuales se

17 Es imperativo aclarar que la recepción histórica que se refiere en este trabajo, no remite a la "historia de la recepción" que promulgaba Panofsky, ya que esta última, retoma positivistamente el concepto de Nachleben y lo acopla a un devenir cronológico de la historia del arte (Didi-Huberman, 2009, p.85-87), concibiendo la recepción como un proceso unidireccional de trasformación de formas pasadas, adaptadas a las nuevas particularidades históricas. La recepción a la cual se remite el trabajo, gira exclusivamente en torno a la generación de nuevos significados y sentidos, que se escapan al espectro cronológico de su producción, que no implican una causalidad lineal frente al significado previo. Se enfoca en el papel del receptor-espectador de las obras (es decir, hacia una historia social de la cultura) y de cómo este modifica el significado ya dado de una obra, generando un nuevo estrato significativo de tiempo, imposible de acoplar a su cronología de producción primaria de la obra, pues esta la menosprecia o infravalora. El Nachleben aquí, remitiría a esa "transformación de sentido" (Didi-Huberman, 2009, p. 82) y la paradoja temporal de lo ahistórico e histórico que la estructura, es decir, la posibilidad de traer hasta el presente una transformación de sentido y significado, que sobrevive paralelamente al significado y sentido primario, y que solo se puede conocer al romper la eucronía imperante. Se aclara entonces que solo en este caso podría ser posible un diálogo entre el Nachleben (principalmente desde esta característica de la paradoja temporal que lo estructura) y la historia de la recepción. Una historia de la recepción no genealógica, sino que aspira culminar.

Con el cuidado que exige una extrapolación de los postulados de Chartier en torno a la historia de la lectura de un texto y, retomando una concepción de texto, más amplia, que articula a todo objeto que puede ser leído o interpretado ${ }^{18}$, se podría establecer que todo texto (ya sea pictórico, musical o escrito) lleva inmerso además del proceso de pre-configuración primaria del significado, un proceso igualmente natural de recepción:

Las obras, en efecto, no tienen sentido estable, universal, fijo. Están investidas de significaciones plurales y móviles, construidas en el reencuentro entre una proposición y una recepción, entre los motivos que les dan su estructura y las competencias y expectativas de los públicos que se adueñan de ellas (Chartier, 1992, p.11).

Donde esos públicos, receptores de las mismas las "apropian"19, y por ende, las distorsionan, las re-inventan, las connotan, es decir, las re-significan. Y son estos actos de apropiación

se realiza desde la posibilidad de una voluntad que desestructura la génesis.

18 "Los textos no son solo escritos, sino también los hablados, los actuados y aun de otros tipos; un poema, una pintura y una pieza de teatro son ejemplos de textos. Van, pues más allá de la palabra y el enunciado" (Beuchot, 2016,p.13)

19 "La apropiación tal como la entendemos nosotros apunta a una historia social de usos e interpretaciones, relacionados con sus determinaciones fundamentales e inscritos en las prácticas específicas que los producen" (Chartier, 1992, p. 53). 
Vallejo Erazo, E. A. (2021). Sobre la apropiación de la escultura de San Ignacio de Loyola o el Lenin connotado. Estudios Latinoamericanos, ISSN (Impr) 0123-0301- ISSN (en línea) 2665-329X, 48, 145-168.

y de re-significación los que deben ser re-valorados históricamente, ya que, las interpretaciones y lecturas no son individuales, ahistóricas o universales, surgen de prácticas temporalmente contextualizadas y específicas de lectura, enmarcadas en espacios ${ }^{20} \mathrm{y}$ costumbres, en modelos y entramados simbólicos que las hacen posibles. Por tanto y en ese orden de ideas, su estudio debe pensarse como el de una representación. Esta apropiación de la imagen, al ser una representación, deja el plano de la interpretación individual de lo visual, para pasar al plano de los entramados socio-culturales de la comunidad diversificada que los interpreta:

Se asume de manera explícita la idea de que las gentes no tienen una actitud pasiva frente a las imágenes que se encargan a un determinado artífice, que se adquieren en una tienda, que se reciben como obsequio o que se legan en un testamen-

20 Es interesante observar que la re-significación de la imagen tiene un origen exclusivo en la ciudad de Pasto. Esto es posible detallarlo en relación a la descripción que se hace de la imagen en espacios socio-culturales diferentes, en los cuales, la influencia de la leyenda no ha distorsionado o connotado la interpretación. Véase un ejemplo de ello, tomando como referencia un ensayo sobre Eloy A. Campos, en el cual se describe la intención y representación primaria de la imagen: "La fama de don Eloy A Campos se ha extendido fuera del Ecuador, recordamos que, para Colombia, trabajó en mármol de las canteras de Tarqui una gigantesca escultura de San Ignacio de Loyola" (El Tiempo, 1957, p.195). No se atribuye, ni se duda del significado de la obra, puede que hasta por la misma diferencia en las categorías de percepción de aquel territorio, frente al nariñense, sea que la imagen no connote a simple vista a Lenin. to, y que es factible para el historiador, por lo menos, intentar establecer de manera documentada las diversas y complejas relaciones que las gentes establecen con las imágenes. Es por eso que en gran medida el eje del análisis se separa de la idea habitual de un espectador que se ve afectado por una determinada imagen, e introduce preguntas que tienen que ver de manera directa con lo que las gentes hacen con las imágenes [...] se trata entonces de observar los usos que las gentes dan a las imágenes y cómo se generan esos usos apropiaciones concretas (Pérez Pérez, 2016, p. XIX)

Analicemos entonces la implicación de esa recepción de los espectadores frente a la imagen de San Ignacio de Loyola. Como aquella apropiación ha cambiado desde el origen de la leyenda hasta el presente, cómo se justifica y cómo ello nos arrojaría una posibilidad de comprensión de formas de pensar y percibir la realidad que no serían tangibles reconocer por otros medios.

\section{Heterocronicidad y apropiación}

Para desarrollar lo anteriormente establecido, es pertinente iniciar este apartado tomando como referencia la base denotativa con la cual las dos interpretaciones antes nombradas se han fundamentado, es decir, una descripción formal de la escultura (Panosfky,1976, p.15): Ubicada en el atrio, específicamente en el parteluz, la estatua de alabastro reposa sobre una columna dórica de igual material, la cual permite que la escultura de por sí alta, se suspenda a más de dos metros del suelo. La 
efigie retrata a un personaje alopécico de mediana edad, de barba y bigote corto, de nariz aguileña, frente amplia y sin arrugas, mirada puesta en el horizonte, pero sin profundidad, labios gruesos y semblante circunspecto y de serenidad. Sobre su espalda se puede apreciar un manteo que cae verticalmente y se oculta tras la bandera que porta en su mano derecha, pero que vuelve a sobresalir levantado por el movimiento de aquel brazo. La mano izquierda suspendida en una posición natural, recoge el manteo que sobresale de su espalda hacia el lado izquierdo. La posición de este brazo y los detalles que se observan en conjunto recuerdan la tradición andaluza barroca de imaginaria Ignaciana, con algunas variaciones especificadas entre corchetes; "dedos individualizados, con las venas que resaltan en la mano derecha [como en la izquierda], la amplitud del cuello en la sotana y el manteo, la barba y el bigote rodeando una boca semiabierta [en este caso completamente cerrada]" (Garcia, 1991, p.74). En su brazo derecho se empuña una asta que sostiene una bandera, un lábaro o un estandarte (no se especifica) más alto que el personaje representado, del cual resalta su moharra y parte de su paño. Este paño, inmóvil, no ondeado, se entrama con el asta y reaparece a la altura de la mano que la porta, desciende sobre la efigie cubriendo su pecho y gran parte de su ceñidor, y finaliza perdiéndose detrás su pie izquierdo. En su pecho, se detalla el monograma de Jesús, JHS, con una cruz sobre la H, acordonado por unas llamas que surgen desde el centro del pecho y que comienzan a expandirse, característica clásica de los atributos ignacianos, como lo describe
Carmona (2003); "un corazón flamígero, en alusión a la intensidad de su amor por Dios" (p.194)

Las características pre-iconográficas que justifican la leyenda de Lenin, se basan en detalles no delineados que dejan espacio a connotaciones simbólicas y que conllevan a una asociación temática diferente a la evidente; como el amplio cuello que apartemente deja entrever un alzacuello no perfectamente esculpido, interpretado visualmente como el cuello de una camisa, acompañado de un pequeño nudo de corbata y un cuerpo de corbata que se pierde debajo de la sotana, o el calzado que se asoma entre la sotana y el paño de la bandera, que no se asemeja en el imaginario popular al calzado característico de los jesuitas, es decir sandalias, pero que si se asimila al calzado propio de Lenin, o de las guerrerillas de izquierda. Súmese a ello ambigüedades iconográficas en algunos de sus detalles, que conducen a trasformaciones simbólicas, como la postura erguida de la escultura que denota autoridad, y que no corresponde a la prefiguración hecha por el padre Fernández, simbolizando para la leyenda una clara alusión a los valores simbólicos de Lenin, también entre en este conjunto de detalles iconologicos se encuentra la bandera o el lábaro que rodea a la efigie, que no simbolizaría la misión de evangelización propia de la compañía de Jesús, ni el cuarto voto del santo respectivamente, ni tampoco hace alusión al fundador de la orden, sino que en verdad sería un símbolo de la libertad y de revolución. Todo ello sumado, a una distintiva semejanza facial de San Ignacio de Loyola y Lenin, 
Vallejo Erazo, E. A. (2021). Sobre la apropiación de la escultura de San Ignacio de Loyola o el Lenin connotado. Estudios Latinoamericanos, ISSN (Impr) 0123-0301- ISSN (en línea) 2665-329X, 48, 145-168.

harían concluir para una parte de la sociedad, que la imagen se asemeja más a este líder bolchevique, que a un santo de la cristiandad.

Pero sobre esas mismas características formales, se podría desmentir esta leyenda y encontrar el significado primario de la obra. Retomando el análisis iconográfico que plantea Panofski (1976,p. 16) la combinación de los temas existentes en la escultura conllevarían a determinar el objetivo representacional de la obra, es decir, que posee una coherencia estilística, temática e histórica de la tradición de imaginería Ignacia: la tan cuestionada "bandera" que la escultura porta en la mano derecha, objeto de significación polivante, hace parte también(como lo ya mencionado) de la tradición de iconográfica ignaciana, ejemplo de ello es la escultura del santo, ubicada en la iglesia de San francisco en Cádiz, atribuida a Juan de Mesa, la cual porta un lábaro en su mano derecha, o igualmente presente en la obra "San Ignacio de Loyola" de Sanchez Coello (conocido como uno de los primeros referentes desde los cuales surge la iconografía ignaciana), de 1676, ubicada en la Iglesia de Ntra. Sra. de la Asunción, en Valdemoro, que permite observar un ángel que porta una bandera con las siglas JHS y que acompaña al santo en su prédica; o la que para el presente autor es la obra más importante referenciada, puesto que sorprende por la semejanza con la escultura de Pasto; el vitral ubicado en el Santuario de Loyola, en la ciudad de Azpeitia (Figura 3), en el norte de España, en el cual las similitudes es- téticas de ambas obras, permitirían inferir que el autor ecuatoriano tomó como referente el vitral español, para la realización de su escultura. Sobre la sotana o la forma de las manos o el rostro, son aspectos iconográficos que se representan desde los primeros retratos de Jacobino del Conte hacia el año de 1574 (García, 1991).

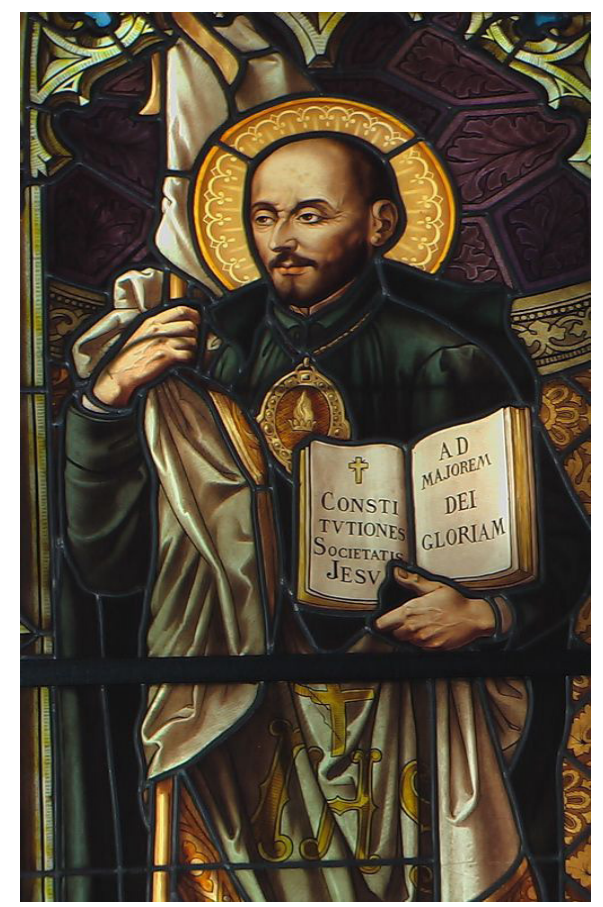

Figura. 3. Detalle de vitral de San Ignacio de Loyola. Ubicado en el Santuario y Basílica de San Ignacio de Loyola, Azpeitia. Fotografía Anónima.

Si se tomara simplemente este estudio iconográfico, sobre el cual está basada la explicación y al mismo tiempo la refutación de leyenda, esta simplemente se agotaría sobre sí misma, ya que aquel modelo de historia-deducción desemboca, como parafrasea Antonio Oviedo del pensamiento de Didi-Huberman, "en la negación de la temporalidad de su objeto y no con- 
templa la historicidad especifica que le concierne" (Didi-Huberman, 2018, p.18), es decir, se limita a una eurocronia, propia de los estudios formales de la obra. Por tal motivo, el entender su trasformación connotativa, su movimiento, su heterocronicidad ${ }^{21}$, conllevaría a hacer tangibles capas informacionales ocultas, orígenes latentes que permiten dar el paso a preguntas más complejas que la simple cuestión sobre su origen generativo.

Esta latencia y/o supervivencia $(\mathrm{Na}-$ chleben) de lo pasado en el presente de la "imagen"22 desarma la historia lineal

21 Si bien Didi-Huberman desarrolla su heterocronia principalmente en relación a la estructura interna, y compositiva de las obras, en este apartado, se retoma la plasticidad innata de dicha categoría y se la inserta al plano de la recepción.

22 Se implícita el concepto Benjaminiano de imagen que cita Didi-Huberman (2018) y que complementa la conceptualización de imagen ya establecida en párrafos precedentes, ahora agregando dos componentes esenciales; la supervivencia dialéctica de lo pasado en el presente, en la cual la imagen "es aquello donde el tiempo pasado se encuentra con el ahora en un relámpago formando una constelación. [En decir...] es dialéctica en suspenso. Pues mientras que la relación del presente con el pasado es puramente temporal, continua, la relación del tiempo pasado con el ahora presente es dialéctica: no es algo que se desarrolla, sino una imagen entrecortada" (Didi-Huberman, 2018, p. 170) y un segundo componente más amplio que parte de una nueva manera de comprensión de la historia; "el pasado como hecho de memoria" que se opone a la concepción inerte, estática de lo pasado como hecho objetivo, preexistente al historiador. Para la imagen, esto deviene crucial puesto que apela a una mayor complejidad en los estratos de pasado que abarca; esta deja de pensarse desde la eucrónia y se convierte ahora en materia de supervivencias: "las cosas que han hecho su tiempo no pertenecen simplemen- de causalidades. Provoca un quiebre a lo prefigurado y estático en el historicismo clásico, ya que hace reconocible un contra ritmo, una convergencia de tiempos heterogéneos, que sería difícil reconocer de otro modo. Dicho en otras palabras, sin aquella conciencia de la heterocronicidad y la recepción, la imagen no podría ser pensada, ni estudiada más allá de lo eucrónico, puesto que se escaparía del terreno ya delineado empírica y epistemológicamente por el conocimiento estético e histórico tradicional. La re-significación de la imagen de San Ignacio de Loyola, es un ejemplo claro de dicho proceso de heterocronicidad, de confluencia dialéctica de tiempos, ya que su re-significación adquiere importancia solo al concebir su temporalidad tanto como dialéctica heterogénea. Al escaparse de la línea cronológica del desarrollo de la imagen, la re-significación crea un nuevo origen, que subsiste hasta la actualidad como una nueva imagen mental paralela al significado preestablecido, perfilando la paradoja temporal que estructura a dicha supervivencia.

Ahora bien, ya reconociendo la existencia de la re-significación y su

te a un pasado caduco, desaparecido: porque ellas han devenido receptáculos de recuerdos, ellas han devenido materia de supervivencias" (Didi-Huberman, 2018, p.161). Es entonces que se puede establecer que la imagen, provoca nuevas imágenes (en este caso mentales) que conviven en el ahora paralemente y no en una misma línea cronologica, pero que se proyectan hacia el pasado. Por otra parte, no hay que olvidar que la amplitud de la noción Warburgiana de Nachleben, no puede agotarse en los límites que esta investigación toma; es decir, en su paradoja temporal que lo estructura. 
Vallejo Erazo, E. A. (2021). Sobre la apropiación de la escultura de San Ignacio de Loyola o el Lenin connotado. Estudios Latinoamericanos, ISSN (Impr) 0123-0301- ISSN (en línea) 2665-329X, 48, 145-168.

forma particular de hacer posible dicha existencia en el plano temporal, es viable, abordar las posibilidades que ella brinda para un estudio histórico cultural; o en otras palabras, dejamos a un lado aquella dimensión estructural de la imagen, para pasar ahora al plano netamente de las relaciones obra-espectador que nos comulgan ${ }^{23}$.

Aquí entramos en el terreno de otra paradoja adicional que se genera con la intervención del espectador-receptor. Puesto que la imagen al ya conllevar estructuralmente una paradoja entre lo ahistórico y heterocrónico, anexa ahora una paradoja entre lo diacrónico y sincrónico, que sugiere su historicidad. La imagen de Lenin (que, si bien nace como recepción a la imagen de San Ignacio de Loyola y que llega hasta nuestros días sin modificaciones en su nueva forma originaria) puesta aho-

23 En este punto específico de la investigación se hace tangible la paradoja temporal que el Nachleben conlleva; si bien el nachleben se presenta como ahistorico, ya que, permanece y subsiste hasta nuestros días, paralelamente a la cronología que la imagen desarrolla, también conlleva una diacronicidad y sincronicidad propia de su temporalidad. Esta diacronía nace desde la relación que se crea con el espectador, el espectador la recepciona, la sedimenta sincrónicamente transformándola en el plano de su significación. En otras palabras, la imagen proyectada de Lenin que se desarrolla paralelamente a la imagen eucronica de San Ignacio de Loyola, llega hasta nuestros días sin modificaciones formales, sigue proyectándose como la imagen de Lenin, sin embargo, la lectura simbólica de la imagen de Lenin si cambia. Ello producto de unas circunstancias socio-históricas propias de los tiempos en los cuales fue interpretada; No es lo mismo la carga simbólica de Lenin que proyectaba la imagen en los años 80 , como lo hace en el ahora. ra en el plano de la lectura y relación con los espectadores, adquiere nuevas connotaciones, nuevas atribuciones de significado que son diacrónicas y sedimentadas entre sí, pero que no pueden desprenderse de esta forma heterocronica de concebir la imagen. Estas nuevas atribuciones de significado, hacen que la recepción de la efigie arroje una cierta información histórica de las diferentes formas de interpretación que la han permeado; tanto de las formas que permanecen, como de los aspectos que cambian en el tiempo; hace visibles las pequeñas trasformaciones interpretativas que se desarrollan por nuevas experiencias socio-históricas a las cuales los espectadores están expuestos, como también los espacios de experiencia heredados que se mantienen, estructuran y anteceden (en procesos de larga duración Kosellekiana y no Braudeliana) su forma de interpretación.

Se hace posible estudiar ahora la recepción de la imagen en su proceso dialectico de interpretación, que comulga paradójicamente lo sincrónico de las interpretaciones, con lo diacrónico de su desarrollo, y lo ahistórico que las sedimenta. Ello, conlleva a esbozar en algunas de sus líneas, la transformación dialéctica de la forma de pensar, concebir y leer la realidad propia de la región, es decir, una parte de la historia de los modos de interpretar la realidad.

Para finalizar, realizaremos algunos esbozos (que por la extensión de este trabajo no es posible darles la debida exposición) del posible abordaje investigativo para identificar y com- 
prender aquellos cambios de interpretación que se han dado a la imagen, no refiriéndonos a la recepción de la imagen de San Ignacio de Loyola hacia Lenin, ya que esto se expuso en los anteriores apartados, sino que analizaremos exclusivamente las re-interpretaciones que se ha dado de la imagen concebida como la efigie de Lenin (como tipo de origen generativo), es decir, solo sobre esta línea cronológica que evoca al líder bolchevique.

A la hora de identificar los cambios de interpretación dados a la imagen, se plantea tomar diferentes marcas temporales relativamente cercanas entre sí (ya que la vida de la imagen y su ubicación en la iglesia de Cristo Rey no puede rastrearse antes de 1948) y con ellas ubicar las diferentes versiones asignadas a la imagen; en la escritura e investigación de este trabajo se han rastreado tres posibles marcas temporales que ubican dos tipos de lectura un tanto disímiles sobre la importancia y significado de dicha imagen para la ciudad. La primera, remite al contexto en el cual, según fuentes orales ${ }^{24}$, surge la leyenda, es decir, la década de los 80 y 90 y por último, nuestro propio presente hacia el cual se ha proyectado la leyenda. Ello permitirá rastrear no solo algunos cambios que han existido en la conformación de los espacios de experiencia, que posibilitan dichas interpretaciones y hacia qué procesos socio-históricos se deben esos cambios,

24 Se remite al escrito de Arévalo Rosero anteriormente referenciado, como también a algunas entrevistas realizadas a narradores orales locales. sino también, lo que ha permanecido en dichas interpretaciones.

Ahora bien, como dicha carga informacional no está sustentada sobre una fuente documental o escrita, sino que se sedimenta sobre el plano de la transmisión oral, no es posible partir tampoco de un estudio ensimismado ni en lo netamente documental, puesto que la información rastreada sería muy poca, ni en la imagen en sí misma, ya que se podría pecar de aislarla de un contexto más amplio de interpretaciones. Por ello, es necesario relocalizar su interpretación hacia el plano de las tramas simbólicas culturales que la engloban. Por tanto, se hace vital localizar otras interpretaciones tanto sincrónicas a la efigie, como diacrónicas (arrojadas hacia lo antaño) de otro tipo de imágenes y manifestaciones culturales que conlleven a hacer visible este marco heredado que se encuentra latente a las mismas y que las conecta. En ese orden de ideas se pondrá a dialogar la lectura de esta efigie con otros objetos culturales sincrónicamente y diacrónicamente producidos y recepcionados, ya que, guardan varias similitudes importantes en algunos de los aspectos que engloba su lectura e interpretación.

Serna y Pons (2005), en su revisión de la nueva historia cultural, posibilitan una aproximación a ese cambio teórico-metodológico requerido, al referirse al abordaje que han hecho los historiadores del "Colegio invisible"; aquellos objetos de estudio de la historia cultural no deben abordarse desde una visión metodológica clásica y es- 
Vallejo Erazo, E. A. (2021). Sobre la apropiación de la escultura de San Ignacio de Loyola o el Lenin connotado. Estudios Latinoamericanos, ISSN (Impr) 0123-0301- ISSN (en línea) 2665-329X, 48, 145-168.

pecializada, es decir, estudiados como objetos de la historia del arte, o la historia social o cultural. Por el contrario, deben ser reconocidos como objetos de estudio diferenciados de aquellos tipos de historia. Los objetos

Son vistos ahora como productos complejos que se relacionan entre sí a través de esa mirada cultural que aprecia sus vínculos, de modo que un libro tal vez tenga más en común con un lienzo o con un programa televisivo que con otro volumen perteneciente al mismo género. Eso obliga al historiador cultural no solo a saber de literatura o arte, sino a atravesar los dominios y las fronteras académicas. (Serna y Pons, 2005, p.5)

El estudio que planteamos entonces no solo retomaría estas recepciones de la imagen, sino que las triangularía con otras latencias interpretativas dadas a otros objetos y manifestaciones culturales en la región. Entre ellas se podría citar: la religiosidad popular de la Virgen de Las Lajas (Ferro Meina, 2004), el mitoide identitario de Agustín Agualongo, la elaboración y quema de los "Años viejos", entre otras. Que analizadas en una dimensión tanto sincrónica como diacrónica dejaría esbozar esa conformación del utillaje mental de los habitantes de la ciudad, observando lo que ha permanecido en las formas de interpretar la realidad y lo que ha cambiado conforme a las nuevas experiencias adquiridas.

\section{A manera de cierre}

En el presente trabajo nos propu- simos dar apertura a la posibilidad de un campo de investigación ciertamente no desarrollado a cabalidad tanto en la región como fuera de ella, la historia de la recepción. Para ello se esbozó el tratamiento teórico que dicho campo de investigación requería y las posibilidades que este plantea a la luz de un lente interdisciplinar que se escape de los limites disciplinares tanto de la historia del arte, como de la historia cultural. Postulando una investigación de la recepción que no reproduzca nociones monocrónicas del tiempo, en las cuales se las interprete como una gama de posibilidades temporales que se trastocan, entrecruzan y chocan entre sí.

Las posibilidades de estudio de la re-significación de la imagen son amplias a la luz de un nuevo lente histórico que las interprete. Por la estructura de este trabajo no es posible desarrollar una investigación a profundidad de dicho tema, ya que requeriría una extensión mucho mayor para realizarlo, por tanto, este artículo no busca agotar sus investigaciones, da un pequeño esbozo a la posibilidad interpretativa de la connotación de la escultura, como latencia en un entramado de re-significaciones, símbolos y prácticas surgidas por aquel utillaje mental especifico que se manifestó colectivamente desde las últimas décadas del siglo pasado, paralelamente entre la alta cultura y la popular.

Por otra parte, las consideraciones frente a una categoría tan mitificada como la anacronia requieren una aclaración. Lo planteado como anacrónico 
tradicionalmente es dejado fuera de los anales de la historia, sin embargo, desde Moxey (2015), lo anacrónico conduce hacia otro tipo de interpretación, un nuevo lente que permite reposicionar, en el tiempo connotaciones anteriormente infravaloradas. Lo anacrónico, como fenómeno no impuesto por el historiador, sino como circunstancia existente en la interpretación y revalorización de las imágenes, hechas por la comunidad, son insumos o fuentes de interés primario.

Sobre los márgenes aparentemente escasos de información, hay que recordar que los límites de información que dan los objetos o producciones del hombre, son dados como diría Febvre (1975) exclusivamente por las limitantes teóricas y epistemológicas que posea el historiador. La información que arroje una fuente solo se agota en la capacidad del historiador para interrogarla, desde un plano semiótico, se agregaría que toda connotación de una obra, que se sedimenta sobre los aspectos denotativos que esta posee, es un insumo informacional de primera mano, que permite llegar a comprender los procesos de recepción de las mismas, de cómo los receptores han leído e interpretado la obra y como la han trasformado. En ese orden de ideas, no es una empresa menor investigar sobre objetos que se han re-significado a través del tiempo, pues es gracias a ellas, que se puede obtener una perceptiva investigativa única que permitiría acercarse a la comprensión histórica de las estructuras de pensamiento colectivo, sus manifestaciones y representaciones, y comprender aspectos que en otros objetos de investigación pasarían desapercibidos. No hay objetos frívolos, ni fuentes inservibles como diría serna y Pons (2005) "es el historiador quien selecciona lo que es importante, y no en menor grado que si se tratara de un relato sobre una célebre batalla o la vida de un conocido monarca” (p.25)

Para finalizar, es pertinente presentar algunas consideraciones sobre el enfoque hermenéutico utilizado y su pertinencia en la no estatización del significado de la imagen. Las interpretaciones realizadas en este trabajo, no corresponden a un agotamiento conclusivo del proceso de re-significación e interpretación de la escultura de San Ignacio de Loyola-Lenin, se deben enmarcar en una perspectiva de hermenéutica analógica. Con ello no se quiere determinar que los estudios visuales e históricos de la escultura estén determinados exclusivamente por este lente observador, por el contrario, la hermenéutica analógica da apertura a la posibilidad interpretativa hacia horizontes no tratados antes en la historia del arte regional.

Si bien, este trabajo se enfoca en el estudio de las re-significaciones, solventado en una teoría receptiva de la obra de arte, no se olvida que la interpretación no su fin último; se concuerda con Didi-Huberman (2009) y Keint Moxey (2015), en que el proceso de traducción, es decir, el acto de decodificación de un lenguaje pictórico hacia una codificación en el lenguaje 
Vallejo Erazo, E. A. (2021). Sobre la apropiación de la escultura de San Ignacio de Loyola o el Lenin connotado. Estudios Latinoamericanos, ISSN (Impr) 0123-0301- ISSN (en línea) 2665-329X, 48, 145-168.

verbal, es vital y necesario para adentrarse históricamente en la obra, pero no la delimita. Pero no hay que olvidar que todas las interpretaciones surgen de un paradigma hermenéutico occidental, que aboga por hallar las profundidades significativas de los objetos que interpreta (Gumbrecht, 2005): Los análisis iconográficos que se enfocan en hallar un porqué a las botas de la escultura, o la postura erguida, o la bandera que recubre a este San Ignacio de Loyola, son traducciones de lo visual al lenguaje lingüístico, generando nuevos tipos de imágenes y obras connotadas a la obra original (materialmente hablando), esas lecturas, son deseos por hallar el significado oculto a simple vista, de penetrar en las profundidades significativas de lo visual. No obstante, se está dejando a un lado la posibilidad de una "producción de presencia" (Gumbrecht, 2005) que genera la obra con el espectador del ahora, no hay que olvidar que la obra transmite y produce un goce emotivo (también histórico) que escapa al lenguaje, una voz directa que conecta fenomenológica y ontológicamente a la escultura con el espectador. ¿Existe, se preguntaría el autor para finalizar, esta producción de presencia, teóricamente definida, que se desarrolle en el ahora, frente a la escultura anteriormente tratada? O isolo existen significados históricos que se contraponen entre sí?

\section{Referencias}

Agreda, J. V. (2002). Iglesias de Pasto (II parte). En, Manual de historia de Pasto. Tomo V, pp.282-305. Pasto, Colombia: Academia Nariñense de Historia y Alcaldía Municipal de Pasto.

Alcala, L. (2014). Pintura en Hispanoamérica 1550-1820. México: Fomento Cultural Banamex/El Viso.

Alvarez, J. (1985). La compañía de Jesús en Pasto. Pasto, Colombia: Tipografía Javier.

Arévalo Rosero, F. (23, Julio, 2013). Vladimir Lenin “infiltrado” en Pasto. Las dos orillas. Recuperado de https://www.las2orillas.co/la-estatua-de-vladimir-lenin-en-pasto/

Bastidas Urresty, J. (2000). Historia Urbana de Pasto. Bogotá, Colombia: Ediciones testimonio.

Beuchot, M. (2016). Hechos e interpretaciones. Hacia una hermenéutica analógica. México: Fondo de cultura económica

Benjamín, W. (2013). Tesis sobre la historia y otros fragmentos. Colombia: Ediciones desde abajo.

Brugiere, A. (1991). Diccionario Akal de ciencias históricas. Madrid: Akal.

Carmona Muela, J. (2003). Iconografía de los santos. Madrid, España: Ediciones istmo.

Crux, D. (2014). "Pequeños relatos de la historia.", en el grupo de Facebook "Cuenca de Antaño”. Recuperado de https:/www.facebook.com/notes/dylan-crux/peque\%C3\%B1os-relatos-de-la-historia/10202129773844188/

Chartier, R. (1992). El mundo como representación. Barcelona, España: Gedisa.

Cohen, H. (1902). Logik der erkenntnis (System der philosophie, I). Berlin, Cassier.

Debray, R. (2007). “Transmitir más, comunicar menos”. A Parte Rei. Revista de filosofía (No.50), pp.1-13. Recuperado de http://serbal.pntic.mec.es/ cmunoz11/debray50. pdf 
Didi-Huberman, G. (2009). La imagen superviviente. Historia del arte y tiempo de los fantasmas según Aby Warburg. Madrid: Abada.

Didi-Huberman, G. (2018). Ante el tiempo. Historia del arte y anacronismo de las imágenes. Buenos Aires: Adriana Hidalgo editora.

Editorial El Tiempo. (1957). El Libro de oro. Edición conmemorativa del IV centenario de la fundación española de Cuenca del Ecuador. Cuenca, Ecuador: Editorial El Tiempo

Febvre, L. (1975). Combates por la historia. Barcelona, España: Ariel.

Ferro Medina, G. (2004). Geografía de lo sagrado: El culto a la virgen de las lajas. Bogotá: Universidad de los Andes, Ediciones Uniandes.

García Guitierres, F. (1991). "San Ignacio de Loyola en la pintura y escultura andalucia”. Boletín de bellas artes, (No. 19), pp. 49-84. Recuperado de https://www.realacademiabellasartessevilla.com/wp-content/uploads/2017/03/1.3.-Disertaci\%C3\%B3n-3.-FERNANDO-GARC\%C3\%8DA-GUTI\%C3\%89RREZ.pdf

Gombrich, E. (2010). Arte e ilusión. Estudios sobre la psicología de la representación pictórica. New York: Phaidon.

Gumbrecht, H. U. (2005). Producción de presencia. Lo que el significado no puede transmitir. México: Universidad Iberoamericana.

Koselleck, R. (1993). Futuro pasado. Para una semántica de los tiempos históricos. Buenos Aires: Paidos.

"La inauguración del templo de Cristo Rey". (Diciembre, 1942). Ilustración Nariñense, Vol. 81, pp.31-32.

"La terminación del templo de Cristo Rey". (Enero, 1945). Ilustración Nariñense, Vol. 89, pp-41- 43.

Martínez Cleves, F.R. (2018). Pensar la historia para no volvernos zombis. Medellín: La Carreta Histórica.

Moreno, L. G. (1979). El municipio de Pasto. En, Cultura Nariñense. (No. 113). pp. 40-58.

Moxey, K. (2015). El tiempo de lo visual. La imagen en la historia. Barcelona, Madrid: Sans Soleil.

Panofsky, E. (1976). Estudios sobre iconografía. Madrid: Alianza Universal.

Paz, O. (2006). Prefacio. Entre orfandad y legitimidad. En: J. Lafaye, Quetzalcóatl y Guadalupe. La formación de la conciencia nacional. (pp.11-24). México: Fondo Económico de Cultura.

Pérez Pérez, M. (2016). Circulación y apropiación de imágenes religiosas en el Nuevo Reino de Granada. Siglos XVI-XVIII. Bogotá: Universidad de los Andes. Facultad de Ciencias Sociales, Departamento de Historia. Ediciones Uniandes.

Scott, James C. (1985). Weapons of the weak. Everyday forms of peasant resistance. New Haven: Yale University Pres

Serna y Pons. (2005). La historia cultural. Autores, obras, lugares. Madrid, España: Akal.

Simiand, F. (1960). Méthode historique et science sociale. Annales. Economies, sociétés, civilisations. 15马 année, (N. 1), pp. 83-119.

Vallejo Erazo, E. A. (2018). Diálogos con la hermenéutica analógica: Hacia la comprensión dialógica del lenguaje musical en la historia. Summa Humanitatis, 10(1), pp. 68-96. Recuperado a partir de http://revistas.pucp.edu.pe/index.php/summa_humanitatis/ article/view/19908

Vivas, J. (29 de Enero 2020). ¿Una iglesia colombiana esconde estatua de revolucionario soviético?. En: El Tiempo. Recuperado de https://www.eltiempo.com/colombia/ otras-ciudades/estatua-en-templo-de-pasto-que-se-parece-a-lider-ruso-vladimir-lenin-456498 